\title{
Mitigation of Pendimethalin Residues as Influenced by the Organic Sources and Bioagents in Sandy Clay Loam Soil Grown with Greengram
}

\author{
C. Bharathi*, P. Murali Arthanari and C. Chinnusamy \\ AICRP on Weed Management (ICAR), Department of Agronomy, Tamil Nadu Agricultural \\ University, Coimbatore, Tamil Nadu, India \\ *Corresponding author
}

Keywords

Dissipation, Green gram, Herbicide residues, Mitigation, Pendimethalin

\section{Article Info}

Accepted:

12 November 2020

Available Online:

10 December 2020

\begin{abstract}
A B S T R A C T
Herbicides use is increasing throughout the globe due to increasing labour cost, choice of application of herbicides, quick weed control in crop and non-cropped areas. Even though the persistence of pendimethalin may be shorter, depends upon the soil, weather and the crop for which its applied will vary in the pendimethalin residues. Hence, pot culture experiments have been carried out with an objective to evaluate various organics and bioagents for their efficiency to degrade the pendimethalin residues faster in the soil. Soil samples were analysed for pendimethalin residues. Residues of pendimethain were extracted using methanol and determined by High Performance Liquid Chromatography (HPLC). It was found that the dissipation was faster under Farm yard manure (FYM), Arbuscular Mycorrhiza (AM) and biochar applied treatments and the slowest degradation was noticed in control during both the years. The lowest half life of 8.57 days (2018-19) and 8.32 days (2019-20) was observed in farm yard manure applied treatment. Application of farm yard manure at $10 \mathrm{t} \mathrm{ha}^{-1}$ or vermicompost at $5 \mathrm{t} \mathrm{ha}^{-1}$ is efficient in reducing the residual concentration of pendimethalin in green gram grown soil. Irrespective of the treatments the pendimethalin residues persisted up to 45 DAHA. On 60 DAHA residues became BDL in FYM and vermicompost applied treatments when compared to others
\end{abstract}

\section{Introduction}

Herbicides have become one of the most important components for efficient weed control and in turn for increasing the agricultural production and to maintain the non-cropped area free from weeds and pests. Herbicides use is increasing throughout the globe due to increasing labour cost, choice of application of herbicides, quick weed control in crop and non-cropped areas. Globally consumption of herbicides is $44 \%$ followed by the insecticides (22\%), fungicides (27\%) and others $(7 \%)$. In India, herbicide use has increased to $30 \%$ during the last 10 years in managing weeds in the country (Sondhia, 2014). As herbicides are chemical in nature and thus excessive and repeated use may pose residue problems, phyto-toxicity to crop plants, residual effect on susceptible intercrops or succeeding crops or non targets organisms and ultimately health hazards due to accumulation of herbicide residues in the soil. In general, herbicides have been 
formulated in such a way that they degrade from the environment after completion of their intended job of controlling weeds, but a few of the herbicides persist in the environment and pose a serious hazard to the succeeding crop and also to the soil environment. However, the herbicide should persist long enough to check weeds until the end of critical period of weed competition but should not persist beyond the crop harvest, as it would be injurious to the sensitive crops grown in rotation. A herbicide is said to be persistent when it may be found to exist in soil in its original or a closely related but phytotoxic form longer than one crop season after its original application (Sondhia, 2013).

Dinitroaniline herbicides are one of the most widely used herbicide groups and play a major role in managing the weed in the agricultural production systems. These herbicides are valued because of their low costs, moderate persistence, and long season weed control in agroecosystems; Pendimethalin, is used for selective control of complex weed flora in pulses, vegetables and oilseeds (Sondhia, 2012). The use of herbicides offers selective and economic control of weeds from the beginning and gives the crop an advantage of a good start and competitive superiority. However, the intensive utilization of these compounds may cause serious risks including environmental safety, water sources' pollution (MontielLeón et al., 2019) as well as human and animal health and crop safety (Mehdizadeh, 2019). Every year in so many countries excessive amounts of soil-applied herbicides are used in agricultural lands; therefore, it seems that the need to provide safe and effective methods for herbicides removal and degradation from environment are very crucial. Nowadays, non-chemical and biological degradation is an important environment friendly strategy for detoxification and dissipation of herbicides from environment (Zhang and Quiao, 2002). However, among soil characteristics, organic matter content is a key factor that has important effect on herbicide degradation and movement in the soil (Gamiz et al., 2017). Application of organic-based fertilizers can improve edaphic qualities and change the fate of any herbicide (Marín-Benito et al., 2019). Some researchers reported that the application of organic-based fertilizers under different soil environment, increases the herbicide degradation and movement in soil (Kravvariti et al., 2010). Different studies showed that the addition of organic matter including manures, composts, and plant residues to soils is a widely accepted non-chemical approach for improving the soil characteristics as well as the different crop production (Pampuro et al., 2017). Cox et al., (2000) concluded that the infertile soils had a minimum effect on herbicide movement; therefore, the presence of organic matter can be considered as an important adsorbent for herbicides. However, the influence of different soil organic amendments on herbicide's fate is very complicated (Briceno et al., 2007). Depending on the type of amendments and chemical structure of applied herbicide, the persistence and dissipation responses of these chemicals can be different (Umar et al., 2012). Even though the persistence of pendimethalin may be moderate, depends upon the soil, weather and the crop for which its applied will vary in the pendimethalin residues. Hence, pot culture experiments have been carried out with green gram with an objective to evaluate various materials for their efficiency to mitigate the pendimethalin residues in the soil.

\section{Materials and Methods}

The experiments have been conducted under All India Coordinated Research Programme on Weed Management, Department of Agronomy, TNAU, Coimbatore during kharif 
seasons of 2018-19 and 2019-20. Soil samples were collected from the field which didn't receive the pendimethalin previously and used for conducting the pot study with the following treatments. The soil used for the study is sandy clay loam in texture and the initial soil characteristics are furnished below.

Initial physico-chemicals characteristics of the soil used for the study

\begin{tabular}{|c|c|c|c|c|c|c|c|c|}
\hline S.No. & Years & \multicolumn{8}{|c|}{ Initial Soil Characteristics } \\
\cline { 3 - 9 } & Texture & $\mathrm{pH}$ & $\begin{array}{c}\mathrm{EC} \mathrm{dS} \\
\mathrm{m}^{-1}\end{array}$ & $\begin{array}{c}\mathrm{OC} \\
\%\end{array}$ & $\begin{array}{c}\text { Available N } \\
\left(\mathrm{kg} \mathrm{ha}^{-1}\right)\end{array}$ & $\begin{array}{c}\text { Available P } \\
\left(\mathrm{kg} \mathrm{ha}^{-1}\right)\end{array}$ & $\begin{array}{c}\text { Available K } \\
\left(\mathrm{kg} \mathrm{ha}^{-1}\right)\end{array}$ \\
\hline 1. & $2018-19$ & $\begin{array}{c}\text { Sandy } \\
\text { clay loam }\end{array}$ & 7.92 & 1.70 & 0.46 & 166.8 & 17.2 & 674 \\
\hline 2. & $2019-20$ & $\begin{array}{c}\text { Sandy } \\
\text { clay loam }\end{array}$ & 7.81 & 1.52 & 0.36 & 167.2 & 19.5 & 542 \\
\hline
\end{tabular}

Treatments were imposed three days before sowing of green gram (Co 8). On $3^{\text {rd }}$ day after green gram sowing, the pendimethalin was applied to each pot@1.0 kg ha ${ }^{-1}$. The details of the treatments as follows.

\begin{tabular}{|c|c|c|c|}
\hline $\mathbf{T}_{1}$ & Farm Yard Manure(FYM) @ $10 \mathrm{t}$ & $\mathbf{T}_{6}$ & Arbuscular Mycorrhiza(AM) @ $10 \mathrm{~kg} \mathrm{ha}^{-1}$ \\
\hline $\mathbf{T}_{2}$ & Vermicompost@ $5 \mathrm{tha}^{-1}$ & $\mathrm{~T}_{7}$ & (x) $10 \mathrm{~kg} \mathrm{ha}^{-1}$ \\
\hline $\mathbf{T}_{\mathbf{3}}$ & Biochar@5 tha ${ }^{-1}$ & $\mathrm{~T}_{8}$ & Urea@100 kg ha ${ }^{-1}$ \\
\hline $\mathbf{T}_{4}$ & Phosphobacteria@10 kg ha ${ }^{-1}$ & $\mathrm{~T}_{9}$ & Maize straw incorporation @ $5 \mathrm{tha}^{-1}$ \\
\hline $\mathbf{T}_{5}$ & Trichoderma@10 kg ha ${ }^{-1}$ & $\mathrm{~T}_{10}$ & Control (no manure/bioagents) \\
\hline
\end{tabular}

Soil samples were collected from a depth of $0-15 \mathrm{~cm}$ on $0,1,3,5,10,15,30$ and 45 days after herbicide application (DAHA) and analysed for pendimethalin residues. Residues of pendimethain were extracted using methanol and determined by High Performance Liquid Chromatography (HPLC). The sample was extracted with 100 $\mathrm{ml}$ methanol as extracting solution after shaking in orbital shaker for $1 \mathrm{hr}$. The suspension was filtered through whatman no.42 filter paper and the extract was evaporated in water bath till the suspension reduced to $10 \mathrm{ml}$. The concentrated extract was transferred to separating funnel and the pendimethalin residue was portioned with 30 $\mathrm{ml}$ of $1 \% \mathrm{NaCl}$ and $50 \mathrm{ml}$ of hexane. The upper organic layer was collected separately. The lower aqueous layer was re-extracted twice with $25 \mathrm{ml}$ hexane each time. The organic layer was pooled and filtered through whatman no. 42 filter paper containing a pinch (2 gm) of anhydrous sodium sulphate. The filtered residue extract was concentrated to dryness using rotary vacuum evaporator. The dried residues of pendimethalin compounds were dissolved in $2 \mathrm{ml}$ acetonitrile HPLC grade solvent for HPLC determination.

\section{Instrumentation}

Pendimethalin residues were determined by HPLC (1200 series) with Diode Array Detector (DAD), binary pump and autosampler with Rheodyne injection system. The pendimethalin compound was separated using Agilent Eclipse XDB - C18, $5 \mu \mathrm{m}$, $4.6 \times 150 \mathrm{~mm}$ column maintained at $30^{\circ} \mathrm{C}$. The instrument was connected to a computer, which converts the signal response in to peak area using EZChrom software (USA). 
Acetonitrile / water (80/20, v/v) was the mobile phase used for the determination. The injection volume of the sample was $20 \mu \mathrm{L}$ with the flow rate of $0.8 \mathrm{~mL} \mathrm{~min}^{-1}$ and detection at $227 \mathrm{~nm}$. Under the given instrumental conditions of HPLC, pendimethalin was resolved at 6.4 minutes (Fig. 1) with a response time of 0.20 seconds.

\section{Method validation}

The stock solution of pendimethalin and its working concentrations were prepared in acetonitrile by diluting the stock solution as described by Janaki et al., (2013) for oxyfluorfen. Then $20 \mu \mathrm{l}$ of each working standards were injected in to HPLC and the peak area was measured for linearity check study.

The analytical calibration graph equation obtained by plotting peak areas in y axis versus concentrations pendimethalin in $\mathrm{x}$ axis was $Y=17819 x+3992$ with the range of 0.01 to $1.0 \mu \mathrm{g} \mathrm{g}^{-1}$. It showed excellent linearity with the correlation coefficient of 0.997 (Fig. 2). Limit of detection (LOD) and Limit of Quantification (LOQ) of pendimethalin were found to be 0.01 and $0.05 \mu \mathrm{g} \mathrm{mL}^{-1}$.

Validity of the method was tested by conducting the recovery experiments through spiking of control soil sample (Janaki et al 2018) with four known concentration (0.05, $0.1,0.5$ and $1.0 \mu \mathrm{g} \mathrm{g}^{-1}$ ) of pendimethalin in three replicates. Then pendimethalin residues were extracted from the spiked sample as described above.

The concentration of pendimethalin residues was determined by comparing the standard calibration curve and peak area of the sample. The blank soil was used to establish the limit of quantification. A quantification limit of $0.01 \mathrm{ppm}$ was used for calculation.

\section{Statistical analysis}

Linearization of degradation curves was performed by transformation of residue concentration $(\mathrm{R})$ and time $(\mathrm{t})$ using general regression equation $y=a+b x$. Based on the decline curves, the intercept (a), slope (b) and half-life $\left(\mathrm{T}_{1 / 2}\right)$ were arrived using first order reaction kinetics function.

\section{Results and Discussion}

\section{Recoveries and detection limit}

To make sure the consistency of the results, method validation is a essential requirement. Linearity precision, accuracy, coefficient determination, LOD and (LOQ) are the factors of method validation.

The recovery experiment showed that the mean recovery of pendimethalin at different levels of fortification in soil was $82.32 \%$ (Table 1). It indicates the described extraction and cleanup method was found to be satisfactory, since the analytical recovery of the pendimethalin the soil was more than 80 percent.

\section{Degradation of pendimethalin in soil}

Pendimethalin residue was analysed from soil samples collected from the pot grown with greengram as test crop at periodic intervals and found that the initial deposition on zero day after herbicide application (2hr) ranged from to $0.535-0.793 \mathrm{mg} \mathrm{kg}^{-1}$ during 2018-19 (Table 2) and from 0.582 to $0.741 \mathrm{mg} \mathrm{kg}^{-1}$ during 2019-20 (Table 3) across different organic sources consisting of microbes application to enhance the degradation of pendimethalin from the soil.

Further it was found that the dissipation was faster under FYM, AM and biochar applied treatments and the slowest degradation was 
noticed in control during both the years. The lowest half life of 8.57 days (2018-19) and 8.32 days (2019-20) was observed in farm yard manure applied treatments. Previous studies have shown that atrazine biodegradation was significantly affected by application of different organic manures (Kadian et al., 2008).

Similarly, Rathod et al., (2010) reported that the half-life values in absence of FYM were higher for dinitroaniline herbicides used and dissipation rate of dinitroanilines increased progressively with time.
The degradation equation, correlation coefficient and half lives are given in Table 4 $\&$ 5. Irrespective of mitigation measures followed, the pendimethalin persisted up to 45 DAS and after 60 DAHA it became Below Detectable Level (BDL) during both the years of experimentation.

The degradation equation, correlation coefficient and half lives are given in Table 4 $\&$ 5. Irrespective of mitigation measures followed, the pendimethalin persisted up to 45 DAHA after 60 DAHA, it became Below Detectable Level (BDL), during both the years of experimentation.

Table.1 Recovery (\%) of pendimethalin from soil

\begin{tabular}{|c|c|c|c|c|c|}
\hline Sample & $\begin{array}{c}\text { Amount } \\
\text { fortified } \\
\left(\boldsymbol{\mu g ~ g}^{-\mathbf{1}}\right)\end{array}$ & $\begin{array}{c}\text { Amount } \\
\text { recovered } \\
\left(\boldsymbol{\mu g ~ g}^{-\mathbf{1}}\right)\end{array}$ & $\begin{array}{c}\text { Recovery } \\
(\mathbf{\%})\end{array}$ & $\begin{array}{c}\text { Average } \\
\text { recovery } \\
(\boldsymbol{\%})\end{array}$ \\
\hline \multirow{2}{*}{ Soil } & 0.05 & 0.039 & 77.89 & \pm 0.0035 & 82.32 \\
\cline { 2 - 6 } & 0.1 & 0.080 & 79.52 & \pm 0.0106 & \\
\cline { 2 - 6 } & 0.5 & 0.413 & 82.63 & \pm 0.0433 \\
\hline
\end{tabular}

Table.2 Persistence of pendimethalin in soil as influenced by the organic sources and microbial application (2018-19)

\begin{tabular}{|c|c|c|c|c|c|c|c|c|c|}
\hline \multirow{2}{*}{\multicolumn{2}{|c|}{ Treatments }} & \multicolumn{8}{|c|}{ Pendimethalin residues $\left(\mathrm{mg} \mathrm{kg}^{-1}\right)$ in soil } \\
\hline & & 0 day & 1 day & 3 day & 5day & 10 day & 15 day & 30 day & 45 day \\
\hline $\mathbf{T}_{1}$ & FYM@10 tha ${ }^{-1}$ & 0.535 & 0.442 & 0.364 & 0.268 & 0.136 & 0.080 & 0.033 & 0.013 \\
\hline $\mathbf{T}_{2}$ & Vermicompost@ 5 tha $^{-1}$ & 0.543 & 0.381 & 0.311 & 0.222 & 0.123 & 0.076 & 0.042 & 0.012 \\
\hline $\mathbf{T}_{3}$ & Biochar@ $5 \mathrm{tha}^{-1}$ & 0.633 & 0.498 & 0.398 & 0.226 & 0.196 & 0.097 & 0.037 & 0.023 \\
\hline $\mathbf{T}_{4}$ & Phosphobacteria@10 kgha ${ }^{-1}$ & 0.620 & 0.459 & 0.355 & 0.272 & 0.142 & 0.082 & 0.046 & 0.028 \\
\hline $\mathbf{T}_{5}$ & Trichoderma@10 kgha ${ }^{-1}$ & 0.574 & 0.492 & 0.405 & 0.329 & 0.211 & 0.108 & 0.062 & 0.035 \\
\hline $\mathbf{T}_{6}$ & AM@ $10 \mathrm{~kg} \mathrm{ha}^{-1}$ & 0.558 & 0.453 & 0.329 & 0.215 & 0.124 & 0.093 & 0.046 & 0.021 \\
\hline $\mathbf{T}_{7}$ & Pseudomonas@10 kg ha ${ }^{-1}$ & 0.606 & 0.541 & 0.395 & 0.292 & 0.165 & 0.086 & 0.054 & 0.024 \\
\hline $\mathbf{T}_{8}$ & Urea@100 kg ha ${ }^{-1}$ & 0.744 & 0.616 & 0.445 & 0.296 & 0.172 & 0.103 & 0.057 & 0.034 \\
\hline $\mathbf{T}_{9}$ & $\begin{array}{l}\text { Crop residue (maize straw) } \\
\text { incorporation @ } 5 \mathrm{t} \mathrm{ha}^{-1}\end{array}$ & 0.588 & 0.389 & 0.348 & 0.294 & 0.196 & 0.115 & 0.069 & 0.035 \\
\hline $\mathbf{T}_{10}$ & Control (no manure/bioagents) & 0.793 & 0.622 & 0.479 & 0.346 & 0.229 & 0.118 & 0.064 & 0.039 \\
\hline
\end{tabular}


Table.3 Persistence of pendimethalin in soil as influenced by the organic sources and microbial application (2019-20)

\begin{tabular}{|c|c|c|c|c|c|c|c|c|c|}
\hline \multirow{2}{*}{\multicolumn{2}{|c|}{ Treatments }} & \multicolumn{8}{|c|}{ Pendimethalin residues $(\mathrm{mg} / \mathrm{kg})$ in soil } \\
\hline & & 0 day & 1 day & 3 day & 5day & 10 day & 15 day & 30 day & 45 day \\
\hline $\mathbf{T}_{1}$ & FYM@10 tha-1 & 0.582 & 0.482 & 0.329 & 0.226 & 0.137 & 0.083 & 0.037 & 0.012 \\
\hline $\mathbf{T}_{2}$ & Vermicompost @ $5 \mathrm{tha}^{-1}$ & 0.725 & 0.598 & 0.397 & 0.294 & 0.165 & 0.086 & 0.053 & 0.018 \\
\hline $\mathbf{T}_{3}$ & Biochar@ @ tha ${ }^{-1}$ & 0.612 & 0.453 & 0.329 & 0.216 & 0.127 & 0.093 & 0.046 & 0.019 \\
\hline $\mathbf{T}_{4}$ & Phosphobacteria@10 kgha-1 & 0.689 & 0.456 & 0.329 & 0.215 & 0.128 & 0.093 & 0.046 & 0.021 \\
\hline $\mathbf{T}_{5}$ & Trichoderma@10 kg ha ${ }^{-1}$ & 0.652 & 0.498 & 0.355 & 0.272 & 0.142 & 0.082 & 0.046 & 0.028 \\
\hline $\mathbf{T}_{6}$ & AM@10 kg ha ${ }^{-1}$ & 0.741 & 0.621 & 0.478 & 0.347 & 0.201 & 0.118 & 0.064 & 0.030 \\
\hline $\mathbf{T}_{7}$ & Pseudomonas@10 kg ha ${ }^{-1}$ & 0.682 & 0.471 & 0.329 & 0.226 & 0.137 & 0.083 & 0.047 & 0.025 \\
\hline $\mathbf{T}_{8}$ & Urea@100 kg ha-1 & 0.599 & 0.387 & 0.348 & 0.292 & 0.188 & 0.115 & 0.069 & 0.038 \\
\hline $\mathbf{T}_{9}$ & $\begin{array}{l}\text { Crop residue (maize straw) } \\
\text { incorporation@ } 5 \mathrm{t} \mathrm{ha}^{-1}\end{array}$ & 0.637 & 0.492 & 0.409 & 0.328 & 0.212 & 0.109 & 0.062 & 0.032 \\
\hline $\mathbf{T}_{10}$ & Control (no manure/bioagents) & 0.708 & 0.613 & 0.446 & 0.301 & 0.173 & 0.104 & 0.068 & 0.041 \\
\hline
\end{tabular}

Table.4 Pendimethalin dissipation equation, correlation coefficient and half lives in soil (2018-19)

\begin{tabular}{|l|l|c|c|c|}
\hline \multicolumn{1}{|c|}{ Treatments } & Regression equation & $\mathbf{R}^{\mathbf{2}}$ & Half life (days) \\
\hline $\mathbf{T}_{\mathbf{1}}$ & FYM @ 10 $\mathrm{t} \mathrm{ha}^{-1}$ & $\mathrm{y}=-0.0809 \mathrm{x}+0.920$ & 0.970 & 8.57 \\
\hline $\mathbf{T}_{\mathbf{2}}$ & ${\text { Vermicompost @ 5 } \mathrm{t} \mathrm{ha}^{-1}}_{\mathbf{T}_{\mathbf{3}}}$ Biochar @ 5 t ha $^{-1}$ & $\mathrm{y}=-0.0782 \mathrm{x}+0.997$ & 0.958 & 8.86 \\
\hline $\mathbf{T}_{\mathbf{4}}$ & Phosphobacteria @ 10 kg ha $^{-1}$ & $\mathrm{y}=-0.0747 \mathrm{x}+0.824$ & 0.931 & 9.28 \\
\hline $\mathbf{T}_{\mathbf{5}}$ & Trichoderma @ 10 kg ha- & $\mathrm{y}=-0.0669 \mathrm{x}+0.925$ & 0.903 & 10.36 \\
\hline $\mathbf{T}_{\mathbf{6}}$ & AM @ 10 kg ha & $\mathrm{y}=-0.062 \mathrm{x}+0.800$ & 0.940 & 11.18 \\
\hline $\mathbf{T}_{\mathbf{7}}$ & Pseudomonas @ 10 $\mathrm{kg} \mathrm{ha}^{-1}$ & $\mathrm{y}=-0.0691 \mathrm{x}+0.986$ & 0.931 & 10.03 \\
\hline $\mathbf{T}_{\mathbf{8}}$ & Urea @ 100 kg ha $^{-1}$ & $\mathrm{y}=-0.0704 \mathrm{x}+0.812$ & 0.930 & 9.85 \\
\hline $\mathbf{T}_{\mathbf{9}}$ & Maize straw incorporation @ 5 $\mathrm{tha}^{-1}$ & $\mathrm{y}=-0.0418 \mathrm{x}+0.735$ & 0.886 & 10.66 \\
\hline $\mathbf{T}_{\mathbf{1 0}}$ & Control (no manure/bioagents) & $\mathrm{y}=-0.0475 \mathrm{x}+0.886$ & 0.956 & 11.46 \\
\hline
\end{tabular}

Table.5 Pendimethalin dissipation equation, correlation coefficient and half lives in soil (201920)

\begin{tabular}{|c|c|c|c|c|}
\hline \multicolumn{2}{|r|}{ Treatments } & Regression equation & $\mathbf{R}^{\mathbf{2}}$ & Half life (days) \\
\hline $\mathbf{T}_{1}$ & FYM@10tha ${ }^{-1}$ & $y=-0.0833 x+0.853$ & 0.955 & 8.32 \\
\hline $\mathbf{T}_{2}$ & Vermicompost @ $5 \mathrm{tha}^{-1}$ & $y=-0.0741 x+0.739$ & 0.924 & 9.35 \\
\hline $\mathbf{T}_{3}$ & Biochar@ @ tha ${ }^{-1}$ & $y=-0.0608 x+0.962$ & 0.927 & 9.90 \\
\hline $\mathbf{T}_{4}$ & Phosphobacteria@10 kg ha ${ }^{-1}$ & $y=-0.0696 x+0.969$ & 0.931 & 9.96 \\
\hline $\mathbf{T}_{5}$ & Trichoderma@10 kg ha ${ }^{-1}$ & $y=-0.0678 x+0.897$ & 0.897 & 10.22 \\
\hline $\mathbf{T}_{6}$ & AM@10 kg ha-1 & $y=-0.0649 x+0.654$ & 0.971 & 10.68 \\
\hline $\mathbf{T}_{7}$ & Pseudomonas@10 kg ha ${ }^{-1}$ & $y=-0.0712 x+0.921$ & 0.986 & 10.6 \\
\hline $\mathbf{T}_{8}$ & Urea@100 kg ha ${ }^{-1}$ & $y=-0.0736 x+0.818$ & 0.933 & 9.42 \\
\hline $\mathbf{T}_{9}$ & maize straw Incorporation @ $5 \mathrm{tha}^{-1}$ & $y=-0.0648 x+0.763$ & 0.946 & 10.7 \\
\hline $\mathbf{T}_{10}$ & Control (no manure/bioagents) & $y=-0.0618 x+0.751$ & 0.882 & 11.22 \\
\hline
\end{tabular}


Fig.1 HPLC chromatograms of standard pendimethalin at 0.01 and $0.05 \mu \mathrm{g} \mathrm{ml}^{-1}$
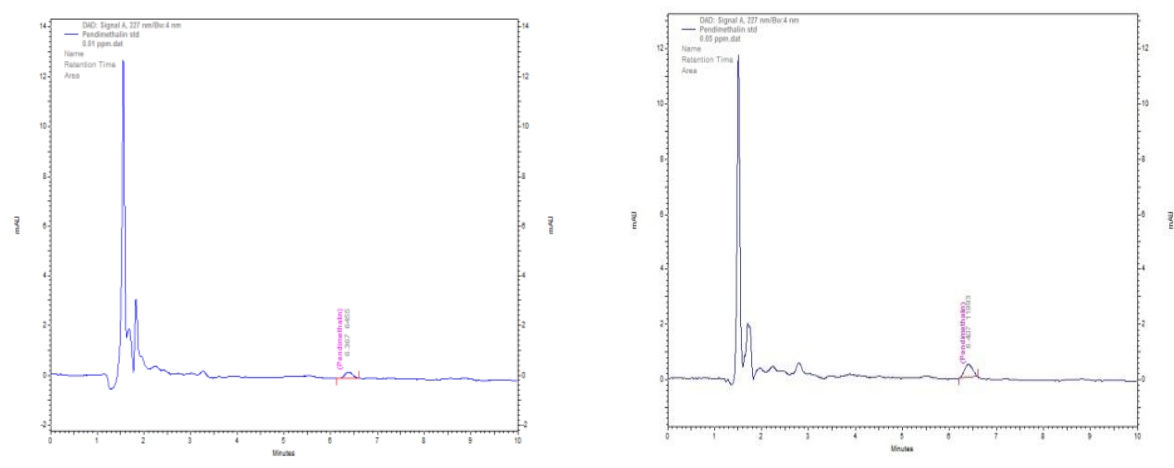

Fig.2 Calibration curve of pendimethalin standard

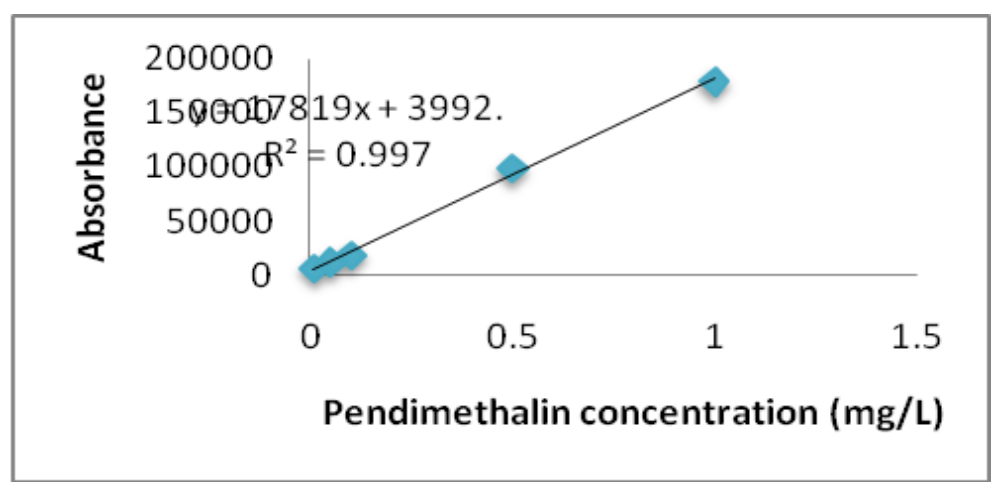

Pendimethalin dissipated quickly in more neutral soil, but the addition of manure can only increase the dissipation rate in acidic soil, indicating that the amendment of manures exerted different effect in pendimethalin dissipation rates in different pH soils (Wen-Ching Chen et al., 2018). On the other hand, the half-life values in absence of FYM were higher for all three dinitroaniline herbicides used (Rathod et al., 2010). Simillarly, pendimethalin herbicide applied in pigeonpea did not show any kind of phytotoxicity on the succeeding green gram even after 150 days after it's application indicating that pendimethalin may not persist in the soil beyond 45 days after its application (Chavan et al., 2018) (Table 5).

Based on the present results it was found that the FYM at $10 \mathrm{t} \mathrm{ha}^{-1}$ or vermicompost at $5 \mathrm{t}$ $\mathrm{ha}^{-1}$ efficient in reducing the residual concentration of pendimethalin in greengram grown soil. This could be due to the enhanced adsorption of the compounds by these sources. The application of FYM degraded the pendimethalin very fast due to the increased microbial population, which resulted the half life of 8.57 days (2018-19) and 8.32 days (2019-20). Many studies reported that the addition of organic amendments can also accelerate or enhance herbicide biodegradation by stimulating microbial growth in different soils (HerreroHernández et al., 2015). Degradation of metribuzin in 24 different soils was investigated by Juhler et al., (2008) and reported that in soils with higher organic matter content, the removal of herbicide was faster than soils with less organic matter content. Metribuzin residues in amended soils were degraded increasingly over time and the intensity of degradation depended on the 
nature of organic amendment. Next to organics pendimethalin degradation was faster in biochar applied treatments. Sugarcane bagasse biochars mixed with clay and a silt loam soils and the pine wood biochar with a loamy sand soil had greater impact in reducing the half life period of pendimethalin (Paul et al., 2015). However, NeetaSoni et al., (2015) observed that biochar application reduced pendimethalin injury for all evaluated crop species and pendimethalin residues can be mitigated by the application of biochar at $0.50 \mathrm{~kg} / \mathrm{m}^{2}$ in soil. The slow degradation by microbes could be ascribed to the low quantity of application when compared to organics. Based on two years of pot culture experiment on mitigation of pendimethalin herbicide residues in sandy clay loam soils grown with green gram, it was observed that the farm yard manure at $10 \mathrm{t} \mathrm{ha}$ ${ }^{1}$ or vermicompost at $5 \mathrm{t} \mathrm{ha}^{-1}$ is efficient in reducing the residual concentration of pendimethalin in green gram grown soil.

\section{Acknowledgement}

The authors gratefully acknowledge the funding support provided by the Directorate of Weed Research (Indian Council of Agricultural Research), Jabalpur through All India Coordinated Research Project on Weed Management and also the laboratory facilities provided by the Tamil Nadu Agricultural University, Coimbatore.

\section{References}

Briceno G, Palma G, Duran N (2007) Influence of organic amendment on the biodegradation and movement of pesticides. Crit Rev Environ Sci Technol. 7:233-271.

Chavan, A.S, V.C. Raj and P.K. Waghmare. (2018). Residues Studies of Pendimethalin and Other Herbicides in Pigeonpea Field Through Bioassay Technique. Int.J.Curr.Microbiol.App.Sci (2018) Special Issue-6: 1866-1873.
Cox L, Celis R, Hermosin MC, Cornejo J, Zsolnay A, Zeller K (2000). Effect of organic amendments on herbicide sorption as related to the nature of the dissolved organic matter. Environ Sci Technol 34:4600-4605.

Gamiz B, Velarde P, Spokas KA, Hermosin MC, Cox L (2017). Biochar soil additions affect herbicide fate: importance of application timing and feedstock species. J Agric Food Chem 63:3109-3117.

Herrero-Hernández E, Marín-Benito JM, Andrades MS, Sánchez-Martín MJ, Rodríguez-Cruz MS (2015) Field versus laboratory experiments to evaluate the fate of azoxystrobin in an amended vineyard soil. J Environ Manag. 163:78-86.

Janaki, P., Sathya Priya, R. and Chinnusamy, C. (2013). Field dissipation of oxyfluorfen in onion and its dynamics in soil under Indian tropical conditions, Journal of Environmental Science and Health, Part B: Pesticides, Food Contaminants, and Agricultural Wastes, 48:11, 941-947

Janaki P, Bhuvanadevi S, Dhananivetha M, Murali-Arthanari P, Chinnusamy C (2018). Persistence of quizalofop ethyl in soil and safety to ground nut by ultrasonic bath extraction and HPLCDAD detection. J Res Weed Sci 1:63-74.

Juhler RK, Henriksen T, Ernstsen V (2008). Impact of basic soil parameters on pesticide disappearance investigated by multivariate partial least square regression and statistics. J Environ Qual 37:1719-1732.

Kadian N, Gupta A, Satya S, Kumari R, Malik A (2008). Biodegradation of herbicide atrazine in contaminated soil using various bioprocessed materials. Biores Technol 99:4642-4647.

Kaleem S, Ansar M, Ali A, Ahmad S. (2006). Efficiency of pendimethalin herbicide against Trianthena monogyna (horse purslane) weeds in cotton crop. Pakistan $\mathbf{J}$ Weed Sci Res. 12: 177-182.

Kravvariti K, Tsiropoulos NG, Karpouzas DG (2010). Degradation and sorption of terbuthylazine and chlorpyrifos in biobed biomixtures from composted cotton crop residues. Pest Manag Sci 66:1122-1128.

Lee Y.D, Kim H.J, Chung J.B, Jeong B.1997. 
Loss of pendimethalin in runoff and leaching from turf grass land under simulated rainfall. J Agril Fd Chem. 48: 5376-5382.

Marín-Benito JM, Carpio MJ, Sánchez-Martín MJ, Rodríguez-Cruz MS (2019). Previous degradation study of two herbicides to simulate their fate in a sandy loam soil: effect of the temperature and the organic amendments. Sci Total Environ 635:13011310.

Montiel-León JM, Vo Duy S, Munoz G, Bouchard MF, Amyot M, Sauvé S. (2019). Quality survey and spatiotemporal variations of atrazine and esethylatrazine in drinking water in Quebec, Canada. Sci Total Environ 671:578-585.

Neeta Soni, Ramon G. Leon, John E. Erickson and Jason A. Ferrell. (2015). Biochar Decreases Atrazine and Pendimethalin Preemergence Herbicidal Activity. Weed Technology. 29(3): 359-366

Pampuro N, Bertora C, Sacco D, Dinuccio E, Grignani C, Balsari P,Cavallo E, Bernal MP. (2017). Fertilizer value and greenhouse gas emissions from solid fraction pig slurry compost pellets. J Agric Sci 155:16461658.

Paul M. White Jr., Thomas L. Potter and Isabel M. Lima. (2015). Sugarcane and pinewood biochar effects on activity and aerobic soil dissipation of metribuzin and pendimethalin. Industrial Crops and Products. 74: 737-744.

Rathod, P.H., R.P.Patel and Amit J. Jhala. (2010). Persistence and management of dinitroaniline herbicides residues in sandy loam soil. Int. J. Environment and Sustainable Development, 9(1/2/3);59-73.

Sondhia S and Singh PK. (2018). Bioefficacy and fate of pendimethalin residues in soil and mature plants in chickpea field. J Res Weed Sci 1:28-339.

Sondhia S. (2012). Dissipation of pendimethalin in soil and its residues in chickpea (Cicer arietinum L.) Under field conditions. Bull Environ Contam Toxicol. 89: 1032-1036.

Sondhia S. (2013). Dissipation of pendimethalin in the soil of field pea (Pisum sativum L.) and detection of terminal residues in plants. Journal of Environmental Science and Health Part B 48(12): 1043-1048.

Sondhia S.(2014). Herbicides residues in soil, water, plants and non-targeted organisms and human health implications: an Indian perspective. Indian Journal of Weed Science 46(1): 66-85.

Umar AF, Tahir F, Larkim M, Oyawoye OM, Musa BL, Yerima MB, Agbo EB. (2012). In-situ biostimulatory effect of selected organic wastes on bacterial atrazine biodegradation. Adv Microbiol 2:587-592.

Wen-Ching Chen, Fang-Yu Hsu \& Jui-Hung Yen. (2018). Effect of green manure amendment on herbicide pendimethalin on soil, Journal of Environmental Science and Health, Part B, 53:1, 87-94,

Zhang J, and Quiao, C. (2002). Novel approaches for remediation of pesticide pollutants. Int $\mathbf{J}$ Environ Pollut 18:423-433.

Zimdahl R, Catizone P, Butcher A. (1984). Degradation of pendimethalin in soil. Weed Sci. 32: 408-412.

\section{How to cite this article:}

Bharathi, C., P. Murali Arthanari and Chinnusamy, C. 2020. Mitigation of Pendimethalin Residues as Influenced by the Organic Sources and Bioagents in Sandy Clay Loam Soil Grown with Greengram. Int.J.Curr.Microbiol.App.Sci. 9(12): 1604-1612.

doi: https://doi.org/10.20546/ijcmas.2020.912.190 